\title{
Interpreting dual ELISA and qPCR data for bacterial kidney disease of salmonids
}

\author{
Shelly L. Nance ${ }^{1}$, Michael Riederer ${ }^{2}$, Tyler Zubkowski ${ }^{3}$, Marc Trudel ${ }^{3}$, \\ Linda D. Rhodes ${ }^{4, *}$ \\ ${ }^{1}$ Aquatic Farms, Ltd., 49-139 Kamehameha Highway, Kaneohe, Hawaii 96744, USA \\ ${ }^{2}$ Department of Biology, University of Washington, Seattle, Washington 98195, USA \\ ${ }^{3}$ Pacific Biological Station, Department of Fisheries and Oceans, 3190 Hammond Bay Road, Nanaimo, \\ British Columbia V9T 6N7, Canada \\ ${ }^{4}$ Northwest Fisheries Science Center, National Marine Fisheries Service, 2725 Montlake Blvd. East, Seattle, \\ Washington 98112, USA
}

\begin{abstract}
Although there are a variety of methods available for the detection of Renibacterium salmoninarum, the causative agent of bacterial kidney disease in salmon and trout, the enzymelinked immunosorbent assay (ELISA) is probably the most widely used method. However, ELISA measures bacterial antigen, which does not necessarily reflect the number of cells present. We hypothesized that dual analysis of kidney tissue by ELISA and a quantitative real-time polymerase chain reaction assay (qPCR) would provide complementary information about antigen level and the number of bacterial genomes. We found that DNA extracted from the insoluble fraction of the ELISA tissue preparation produced the same qPCR result as DNA extracted directly from frozen tissue, permitting true dual analysis of the same tissue sample. We examined kidney tissue in this manner from individual free-ranging juvenile Chinook salmon and antibiotic-treated captive subadult Chinook salmon and observed 3 different patterns of results. Among the majority of fish, there was a strong correlation between the ELISA value and the qPCR value. However, subsets of fish exhibited either low ELISA values with elevated qPCR values or higher ELISA values with very low qPCR values. These observations suggest a conceptual model that allows inferences about the state of infection of individual fish based on dual ELISA/qPCR results. Although this model requires further assessment through experimental infections and treatments, it may have utility in broodstock selection programs that currently apply egg-culling practices based on ELISA alone.
\end{abstract}

KEY WORDS: Bacterial kidney disease - Renibacterium salmoninarum • Diagnostic assays · ELISA · qPCR $\cdot$ Infection state $\cdot$ Oncorhynchus tshawytscha

\section{INTRODUCTION}

Bacterial kidney disease (BKD) of salmonids is a persistent, often debilitating condition frequently observed among stocks of Chinook salmon, coho salmon, and sockeye salmon of the US Pacific Northwest and Alaska (Meyers et al. 2003, Arkoosh et al. 2004, Rhodes et al. 2006). The enzyme-linked immunosorbent assay (ELISA) has been the diagnostic method of choice in regional hatcheries and captive broodstock programs for nearly 2 decades because of several desirable features. The 96-well format permits processing of large sample numbers, and commercially available reagents facilitate inter-laboratory calibration. The procedure is robust because sample preparation is simple, the target antigens are stable and abundant, and the assay has a sensitivity of approximately 20 to $40 \mathrm{ng} \mathrm{ml}^{-1}$ of homogenate (Meyers et al. 1993). Renibacterium salmoninarum secretes abundant quantities of major soluble antigen (MSA), which is the dominant ELISA target (Pascho \& Mulcahy 1987), and tissue accumulations of MSA can persist for up to 2 mo (Pascho et al. 1997). However, the predictive capability of the ELISA can be inaccurate when target antigens in tissue are not correlated with the number of bacteria present. Ad hoc analysis has provided evidence that the amount of MSA 
per cell decreases exponentially as total antigen increases (Hamel \& Anderson 2002). This can be problematic when using ELISA results in the selection of broodstock in captive broodstock programs. Consequently, a variety of diagnostic procedures has been explored, often with the purpose of replacing the ELISA with a more sensitive assay (e.g. Chase et al. 2006, Jansson et al. 2008).

One approach to increasing information content from a tissue sample is to conduct more than one assay. Tissue preparation for ELISA is relatively simple: Fresh or previously frozen tissue is homogenized with phosphate-buffered saline containing the detergent Tween-20, boiled for $10 \mathrm{~min}$, and centrifuged to separate the soluble (used for ELISA) and insoluble (typically discarded) fractions. We reasoned that the genomic DNA from this Gram-positive bacterium would be conserved by this preparation method and would fractionate with the insoluble pellet. We tested this prediction with kidney tissue from returning adult Chinook salmon Oncorhynchus tshawytscha. The ability to conduct dual analysis on a single tissue sample would be advantageous when the amount of tissue is limited. It also allows results to be reported for a single sample, rather than replicate aliquots.

Here, we report studies that examined the consistency between ELISA and quantitative polymerase chain reaction assay (qPCR) results for kidney samples from Chinook salmon. We hypothesized that because ELISA and qPCR measure different bacterial macromolecules (protein and DNA, respectively), there may not be strict correspondence between the assays. We examined tissue from individual free-ranging juvenile fish as representatives of naturally progressing infections. We then examined individual infected subadult females treated with antibiotics to assess the impact of drug treatment on the assays. Based on the results, we propose a model for interpreting the combined results of the 2 diagnostic methods as a framwork for inferences about the infection status of individual fish.

\section{MATERIALS AND METHODS}

Tissue sources and collection. Kidney tissues collected from adult fish ( $\mathrm{n}=25$ ) spawned at a Washington State, USA, hatchery were used to compare qPCR results from DNA extracted from the insoluble pellet from ELISA preparations (ELISA pellet) and DNA extracted directly from fresh tissue (conventional). Tissues were held on ice after collection and transferred to $-20^{\circ} \mathrm{C}$ within $12 \mathrm{~h}$ for storage until processing. Correspondence between ELISA and qPCR values was assessed using 2 different sources of tissue. One source was free-ranging juvenile Chinook salmon $(\mathrm{n}=334)$ collected by the Canadian Program on High Seas Salmon (Department of Fisheries and Oceans, Canada) from the west coast of Vancouver Island to Southeast Alaska from 2002 through 2007 using a rope trawl. Fish bearing a coded wire tag, passive integrated transponder tag, or clipped adipose fin were classified as hatchery origin fish. Whole carcasses were frozen on board the ship. Kidney tissues were subsequently removed from partially thawed fish and stored at $-20^{\circ} \mathrm{C}$ until processing. ELISA and qPCR were performed on separate aliquots of frozen tissue. A second source was a cohort of captive subadult female Chinook salmon $(n=54)$ bearing a natural infection of Renibacterium salmoninarum and exhibiting clinical signs and symptoms of BKD. These fish received a single injection of sterile, distilled water (vehicle control), erythromycin (20 mg kg-1 body weight), or azithromycin (20 $\mathrm{mg} \mathrm{kg}^{-1}$ body weight) in a total volume of $100 \mu \mathrm{l}$ vehicle. Fish were sampled prior to antibiotic treatment and once per month up to 3 mo after treatment with an antibiotic injection. Kidney tissue was collected after euthanasia with MS-222 (100 mg $\mathrm{l}^{-1}$, $\mathrm{pH}$ 7.4) and gill arterial exsanguination, retained on ice $<24 \mathrm{~h}$, then stored at $-20^{\circ} \mathrm{C}$ until processing. ELISA and $\mathrm{qPCR}$ were performed on a single tissue sample, i.e. the ELISA pellet was the source of DNA for qPCR.

Molecular analyses. ELISA was performed by the method of Pascho et al. (1991), using a 1:3 ratio of tissue:phosphate-buffered saline with $0.05 \%$ Tween-20. Categories for ELISA values were set using the thresholds described in Pascho \& Mulcahy (1987; see our Table 1). DNA extractions and qPCR were performed as previously described (Rhodes et al. 2006), except the probe was a 5'-FAM-BHQ1-3' labeled oligonucleotide. This primer-probe set is directed against a stable, single-copy intergenic region of the Renibacterium salmoninarum genome, and it can be used to quantify the number of bacterial cells present. Primer-probe sets directed against the major soluble antigen gene (msa) cannot be used for quantification, because $R$. salmoninarum has a variable number of copies of msa that are identical in sequence depending on the strain (Rhodes et al. 2004). For DNA extractions using the ELISA pellet as the starting material, 20 to $25 \mathrm{mg}$ of the pellet was directly removed. ELISA results were reported as absorbance units at $405 \mathrm{~nm}$ (optical density, $\mathrm{OD}_{405 \mathrm{~nm}}$ ), and $\mathrm{qPCR}$ results were reported as number of genomic units per mg of tissue $\left(\mathrm{gu} \mathrm{mg} \mathrm{m}^{-1}\right.$ ). Assays for antibiotic activity in tissues used the disk diffusion method with Micrococcus luteus, and the detailed method is described in Fairgrieve et al. (2005). Antibiotic activity is reported as $\mu \mathrm{g}$ equivalents $\mathrm{mg}^{-1}$ tissue.

Statistical analyses. Comparison of qPCR results from the ELISA pellet and conventional source mater- 
ial was made by the Wilcoxon signed rank test and Spearman's rank correlation. The effects of gender and fish origin on qPCR values were evaluated by the Mann-Whitney test. Correlations between the ELISA values and qPCR values were examined using Spearman's rank correlation. For the comparisons of qPCR values to ELISA values, the qPCR values were logtransformed [log $(1+$ qPCR value $)]$. Outliers to correlations were identified by inspection using the following criteria: (1) ELISA OD $\leq 0.100$ and $q$ PCR result $>$ $10 \mathrm{gu} \mathrm{mg}^{-1}$ and (2) ELISA OD $\geq 0.200$ and $\mathrm{qPCR}$ result $\leq 10 \mathrm{gu} \mathrm{mg}^{-1}$. Frequencies of fish categorised by ELISA OD and qPCR values were compared by Fisher's exact test.

\section{RESULTS}

\section{Comparison of DNA sources for qPCR}

Tissue aliquots from spawning Chinook salmon were processed in parallel with ELISA pellets and conventional frozen samples. The observed qPCR values spanned 5 log values, ranging between zero and $>200000$ bacterial gu $\mathrm{mg}^{-1}$ (Fig. 1). A comparison of qPCR results for the 2 methods found no difference between the source materials ( $W=59.00,2$-tailed, $\mathrm{p}=$ 0.17 ), and the qPCR results between source materials were strongly correlated $\left(r_{S}=0.88, p<0.0001\right)$. These results indicate that ELISA pellets may be used as a source material for DNA for $\mathrm{qPCR}$, and the qPCR results from ELISA pellets are comparable to those from frozen tissues. As a result, ELISA pellets were used as the DNA source for analysis of the captively reared fish.

\section{Comparison of qPCR and ELISA results}

Results from free-ranging ocean fish. For kidney tissue from juvenile Chinook salmon collected in a high seas monitoring program, neither gender $(U=13680$,

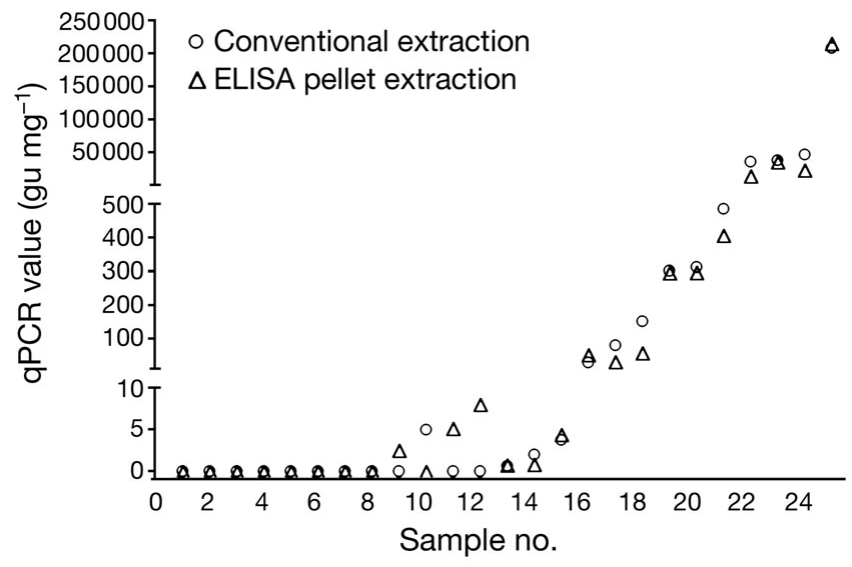

Fig. 1. Oncorhynchus tshawytscha. Comparison of quantitative real-time PCR (qPCR) values per tissue weight for conventional and ELISA pellet source materials from 25 kidney samples. gu: genomic unit

2-tailed, $\mathrm{p}=0.79)$ nor fish origin $(U=9167,2$-tailed, $\mathrm{p}=0.14$ ) affected $\mathrm{qPCR}$ values. Although the mean qPCR values increased at least 10 -fold for each ELISA category, there was considerable variance within categories (Table 1). For example, among the 17 ELISAhigh fish (OD > 1.00), the 10 hatchery-origin fish had qPCR values ranging from 161 to $1 \times 10^{8} \mathrm{gu} \mathrm{mg}^{-1}$ tissue, while 4 of the 7 fish of unknown origin had no detectable bacteria by qPCR (Table 1). There were only 6 ELISA-moderate fish, and 3 of those had no detectable bacteria by qPCR. The majority of fish were ELISA-low (264 of 334), and 215 of those fish exhibited no detectable bacteria by qPCR. Among the ELISAundetectable fish (47 of 334), 2 of these fish exhibited qPCR values $>10 \mathrm{gu} \mathrm{mg}^{-1}$ tissue.

There was a positive correlation between the ELISA and $q$ PCR values $(p<0.0001)$, but the Spearman's rank correlation coefficient was modest, with a $\mathrm{r}_{\mathrm{S}}$ of 0.38 for all fish (Table 2). Using combined ELISA and qPCR criteria (see 'Materials and methods'), inspection of the data suggested that 22 samples were poor fits to the correlation. Some of these samples exhibited higher qPCR values with no detectable ELISA values, while

Table 1. Oncorhynchus tshawytscha. Mean quantitative PCR (qPCR) values (gu $\mathrm{mg}^{-1}$ ) for ELISA-value categories for free-ranging juvenile Chinook salmon collected in a high seas monitoring program. Range and sample size are indicated in parentheses

\begin{tabular}{|c|c|c|c|c|}
\hline & $\begin{array}{l}\text { ELISA-undetectable } \\
\quad(\mathrm{OD}<0.079)\end{array}$ & $\begin{array}{c}\text { ELISA-low } \\
\text { (OD } 0.080-0.199)\end{array}$ & $\begin{array}{l}\text { ELISA-moderate } \\
\text { (OD 0.200-0.999) }\end{array}$ & $\begin{array}{l}\text { ELISA-high } \\
(\mathrm{OD}>1.000)\end{array}$ \\
\hline All fish & $\begin{array}{c}2 \\
(0-96,47)\end{array}$ & $\begin{array}{c}83 \\
(0-7368,264)\end{array}$ & $\begin{array}{c}686 \\
(0-3925,6)\end{array}$ & $\begin{array}{c}9.8 \times 10^{6} \\
\left(0-9.9 \times 10^{7}, 17\right)\end{array}$ \\
\hline Hatchery origin & $\begin{array}{c}0 \\
(0-0,6)\end{array}$ & $\begin{array}{c}6 \\
(0-210,64)\end{array}$ & $\begin{array}{c}143 \\
(143,1)\end{array}$ & $\begin{array}{c}1.1 \times 10^{7} \\
\left(161-9.9 \times 10^{7}, 10\right)\end{array}$ \\
\hline Unknown origin & $\begin{array}{c}3 \\
(0-96,41)\end{array}$ & $\begin{array}{c}108 \\
(0-7368,200)\end{array}$ & $\begin{array}{c}795 \\
(0-3925,5)\end{array}$ & $\begin{array}{c}8.5 \times 10^{6} \\
\left(0-4.0 \times 10^{7}, 7\right)\end{array}$ \\
\hline
\end{tabular}


Table 2. Oncorhynchus tshawytscha. Correlations between quantitative real-time PCR (qPCR) and ELISA values by fish origin for free-ranging juvenile Chinook salmon collected in a high seas monitoring program. $\mathrm{r}_{\mathrm{S}}$ : Spearman's rank correlation coefficient

\begin{tabular}{|lccc|}
\hline & $\mathrm{r}_{\mathrm{S}}$ & $\mathrm{p}$ & $\mathrm{n}$ \\
\hline All fish & 0.38 & $<0.0001$ & 334 \\
Hatchery origin & 0.56 & $<0.0001$ & 81 \\
Unknown origin & 0.32 & $<0.0001$ & 253 \\
\hline
\end{tabular}

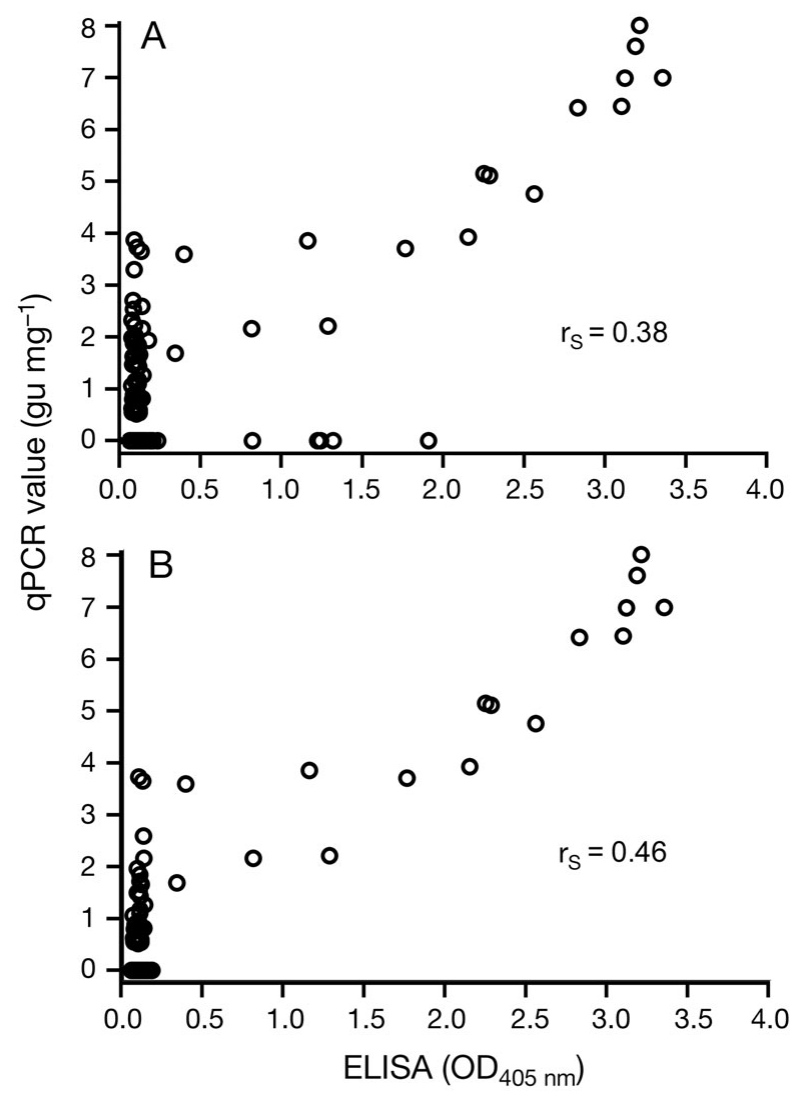

Fig. 2. Oncorhynchus tshawytscha. Corresponding ELISA and log-transformed quantitative real-time PCR (qPCR) values from kidneys of free-ranging, ocean-phase juveniles for (A) all 334 samples and (B) all samples with outliers omitted. Corresponding Spearman's rank correlation coefficients $\left(\mathrm{r}_{\mathrm{S}}\right)$ are shown. OD: optical density; gu: genomic unit

others exhibited a qPCR value of zero with elevated ELISA values (Fig. 2A). If these samples were outliers, their removal should improve the correlation coefficient; when these 22 samples were omitted from the analysis, $\mathrm{r}_{\mathrm{S}}$ increased to 0.46 ( $\mathrm{p}<0.0001$, Fig. 2B).

Results from antibiotic-treated fish. A cohort of subadult female Chinook salmon with a natural infection of Renibacterium salmoninarum was treated by intraperitoneal injection with erythromycin, azithro-
Table 3. Oncorhynchus tshawytscha. Correlations between quantitative real-time PCR (qPCR) and ELISA values for infected subadult female Chinook salmon before antibiotic treatment (pretreatment), treated with antibiotics (azithromycin, erythromycin), or water-treated (water, vehicle control). Fish from all sampling months were combined. $\mathrm{r}_{\mathrm{S}}$ : Spearman's rank correlation coefficient

\begin{tabular}{|lccc|}
\hline & $\mathrm{r}_{\mathrm{S}}$ & $\mathrm{p}$ & $\mathrm{n}$ \\
\hline All groups & 0.67 & $<0.0001$ & 54 \\
Pretreatment & 0.80 & $<0.01$ & 10 \\
Azithromycin & 0.42 & $>0.10$ & 14 \\
Erythromycin & 0.55 & $<0.05$ & 15 \\
Water (control) & 0.78 & $<0.005$ & 15 \\
\hline
\end{tabular}

mycin, or water (vehicle control), and each treatment group was sampled monthly for qPCR and ELISA analysis. Positive correlations between the 2 assays were observed for each treatment group, except for the azithromycin-treated group (Table 3 ). There was a correlation between ELISA and $\mathrm{qPCR}$ values $\left(\mathrm{r}_{\mathrm{S}}=0.67, \mathrm{p}<\right.$

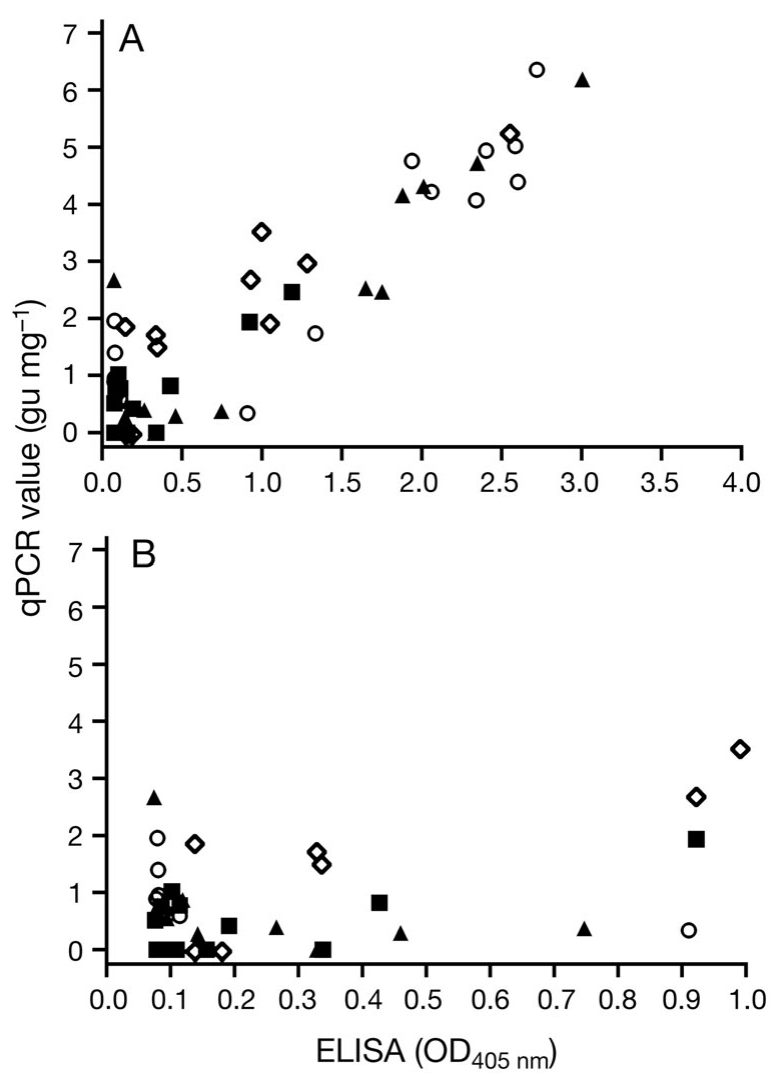

Fig. 3. Oncorhynchus tshawytscha. Corresponding ELISA and log-transformed quantitative real-time PCR (qPCR) values from kidneys of infected subadult female Chinook salmon before treatment (O), treated once with erythromycin $(\boldsymbol{\Delta})$ or azithromycin $(\mathbf{\square})$, or water-treated $(\diamond$, vehicle control) for (A) all 54 samples and (B) samples with an ELISA value $\leq 1.000$. OD: optical density; gu: genomic unit 
0.0001, 2-tailed), which was obvious for samples with higher ELISA values (Fig. 3A). Among samples with an ELISA value $\geq 0.200$, those with low qPCR values (i.e.

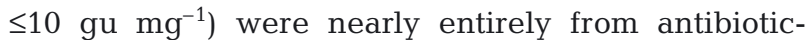
treated fish (6 of 7 fish; Fig. 3B), while those with elevated qPCR values (i.e. $>10 \mathrm{gu} \mathrm{mg}^{-1}$ ) were principally from fish not treated with antibiotics (15 of 23 fish; Fisher's exact test, $\mathrm{p}=0.03,2$-sided). Among the 24 samples with an ELISA value $<0.200,20$ displayed low qPCR values (i.e. $<10 \mathrm{gu} \mathrm{mg}^{-1}$ tissue). However, 4 samples exhibited elevated qPCR values, and 3 of these samples were from pretreatment or water-treated (vehicle control) fish. All azithromycin-treated fish exhibited antibiotic activity in kidney tissue, ranging from 2.4 to $34.5 \mu \mathrm{g}$ equivalents $\mathrm{mg}^{-1}$ tissue $($ median $=13.53 \mu \mathrm{g}$ equivalents $\mathrm{mg}^{-1}$ tissue), and 10 of the 14 fish displayed ELISA values $<0.200$ and $\mathrm{qPCR}$ values $\leq 10 \mathrm{gu} \mathrm{mg}^{-1}$. Fish treated with erythromycin exhibited much lower tissue antibiotic activity, ranging from 0 to $1.8 \mu \mathrm{g}$ equivalents $\mathrm{mg}^{-1}$ tissue. All erythromycin-treated fish with ELISA values $>0.200$ and $\mathrm{qPCR}>10 \mathrm{gu} \mathrm{mg}^{-1}$ had no detectable tissue antibiotic activity, whereas 3 of the 4 fish with ELISA values $>0.200$ and $\mathrm{qPCR} \leq 10 \mathrm{gu} \mathrm{mg}^{-1}$ had detectable tissue antibiotic activity (median $0.97 \mu \mathrm{g}$ equivalents $\mathrm{mg}^{-1}$ tissue).

\section{DISCUSSION}

Pathogen detection is often not a simple positive or negative process. In the case of BKD, multiple assay types and the use of multiple tissues can create a lack of concordance in assigning fish as positive or negative with respect to infection (e.g. Pascho et al. 1998, Bruno et al. 2007), and thus can complicate management decisions, particularly for genetic conservation programs. We have shown that dual analysis of kidney samples by ELISA and qPCR for Renibacterium salmoninarum does not necessarily generate redundant results. Each of these assays measures a different bacterial macromolecule and consequently can report different information about the state of the infection. For many cases, especially those considered to be a severe infection (ELISA $\geq 1.00$ ), there is a close correlation between the 2 assays (Figs. 2A \& 3A). However, we found significant numbers of samples among both free-ranging and captively reared fish that exhibited poor concordance between ELISA and qPCR values. Analysis of replicates and the use of a single sample for both assays make it unlikely that these results are processing or analytical anomalies.

Efforts to compare diagnostic assays for Renibacterium salmoninarum have frequently identi-

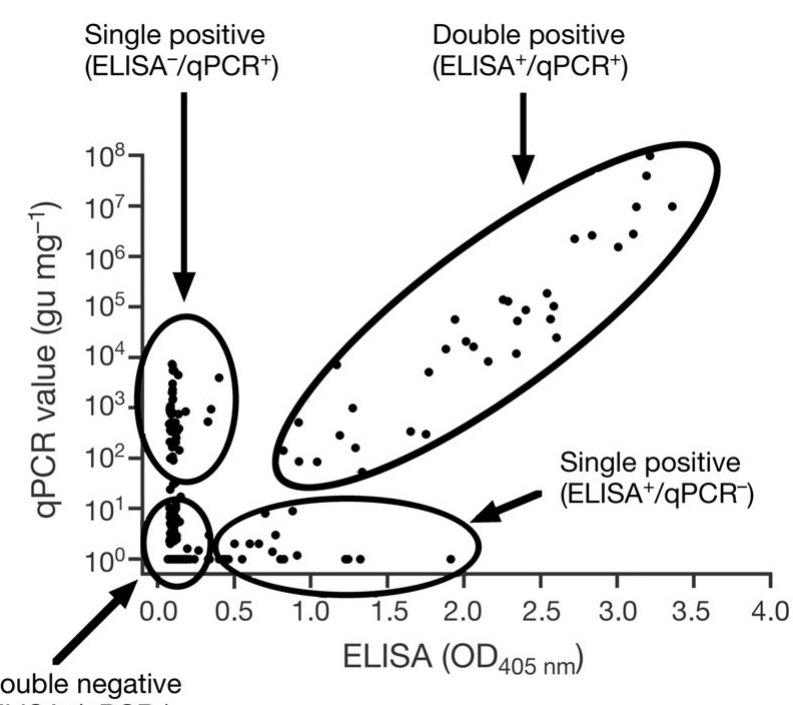

$\left(\mathrm{ELISA}^{-} / \mathrm{qPCR}{ }^{-}\right)$

Fig. 4. Oncorhynchus tshawytscha. Pictorial representation of data point assignments to 1 of 4 categories based on ELISA and quantitative real-time PCR (qPCR) values. OD: optical density; gu: genomic unit

fied samples that did not fit an overall correlation or expected distribution (e.g. Teska et al. 1995, Griffiths et al. 1996, Miriam et al. 1997, Chase \& Pascho 1998, Suzuki \& Sakai 2007). In the context of previous studies using multiple assays, a conceptual model for interpreting our ELISA and qPCR results may be developed. Based on the observed distributions, each sample could be assigned to one of 4 broader categories (Fig. 4): double negative (ELISA ${ }^{-}, \mathrm{qPCR}^{-}$), single positive $\left(\mathrm{ELISA}^{+}, \mathrm{qPCR}^{-}\right.$or $\left.\mathrm{ELISA}^{-}, \mathrm{qPCR}^{+}\right)$, and double positive $\left(\mathrm{ELISA}^{+}, \mathrm{qPCR}^{+}\right)$. For ELISA conducted under our protocol, an OD $<0.200$ would be considered negative, although a more stringent (i.e. lower) value is often adopted for broodstock culling. For qPCR, a sam-

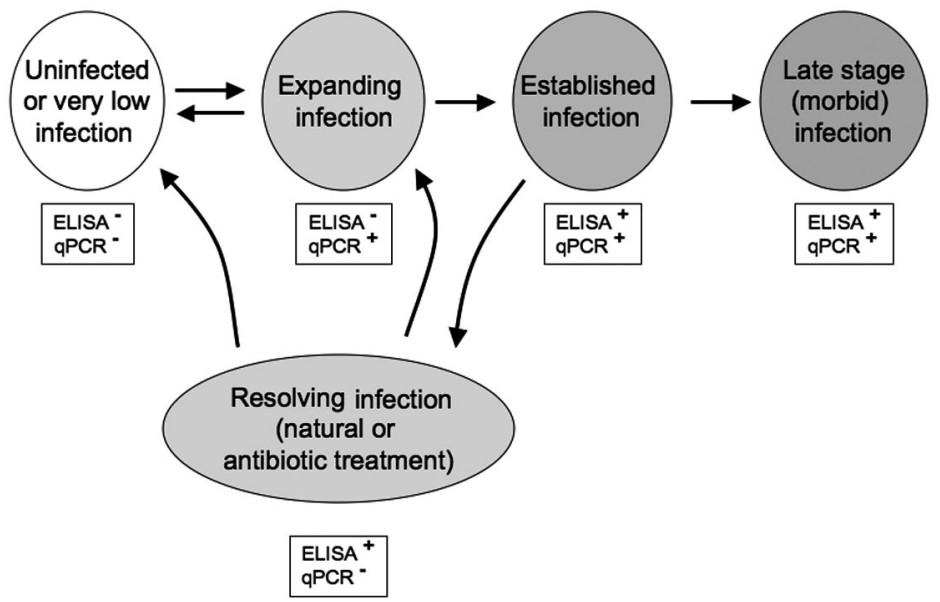

Fig. 5. A model for relating ELISA and quantitative real-time PCR (qPCR) values to infection status 
ple with $\leq 10 \mathrm{gu} \mathrm{mg}^{-1}$ of tissue would be considered negative, because repeated assays of samples in this range typically yield values that include zero (data not shown).

We further propose that the different distribution categories may represent different states of infection (Fig. 5). Uninfected fish or fish with a very low level of infection may have very low or no detectable bacterial DNA and antigen present (double negative). Among the free-ranging, ocean-phase Chinook salmon, more than $78 \%$ of the fish had kidneys that could be classified as double negative. We suggest that during early stages of expansion of infection, proliferating bacteria are rapidly synthesizing DNA with lower rates of extracellular protein synthesis, resulting in single positive samples (ELISA ${ }^{-}$, $\mathrm{qPCR}^{+}$). Among ocean-phase salmon, nearly $15 \%$ of the fish could be assigned to this category, suggesting that these fish had been recently infected, or that these fish experienced conditions that exacerbated existing low-grade infections. If host immune responses can effectively contain and eliminate the early infection, bacterial DNA will be quickly eliminated, and a double negative state is restored. However, if the infection either continues to expand or becomes static, MSA and other ELISA target antigens accumulate disproportionately to the number of bacterial cells, and the tissue becomes positive for both bacterial DNA and antigen. It may be still possible to suppress a double positive infection either through host immune response or through therapeutics, resulting in a single positive state where bacterial antigen, but not bacterial DNA, can be detected $\left(\mathrm{ELISA}^{+}, \mathrm{qPCR}{ }^{-}\right)$. Data from our infected fish treated with antibiotics are consistent with this state on several fronts. The ELISA ${ }^{+}, \mathrm{qPCR}^{-}$subset of fish were dominated by antibiotic-treated individuals, while the ELISA $^{+}, \mathrm{qPCR}^{+}$fish were dominated by fish that had not received antibiotic treatment. All erythromycintreated fish classified as double positives had no detectable tissue antibiotic activity, and those fish that were $\mathrm{ELISA}^{+}$, qPCR ${ }^{-}$had a median antibiotic activity of $0.97 \mu \mathrm{g}$ equivalents $\mathrm{mg}^{-1}$ tissue. Interestingly, all of the azithromycin-treated fish had relatively high tissue antibiotic activity (median activity $13.53 \mu \mathrm{g}$ equivalents $\mathrm{mg}^{-1}$ tissue) and most of those fish were double negatives. These results suggest that these macrolide antibiotics can lower the qPCR values.

A caveat of the data we present is the absence of information about the viability of the bacterial cells. Detection of bacterial DNA or protein is not necessarily indicative of viable cells, which can be confirmed by growth in culture. Analysis for bacterial RNA, which is extremely labile and produced only by living cells, has been proposed as a marker for viable Renibacterium salmoninarum (Cook \& Lynch 1999, Suzuki \& Sakai
2007). Because DNA from R. salmoninarum may persist from nonviable cells, overestimation of cell numbers or false-positive results (when total cell numbers are very low) can result. For the ELISA ${ }^{-}, \mathrm{qPCR}^{+}$cases, demonstrating that DNA was derived from viable cells would be important for interpreting an expanding infection. Interestingly, Suzuki \& Sakai (2007) observed elevated DNA concentrations but minimal or no mRNA or culture growth during the early course of a disease challenge (see also our Fig. 5B), indicating that the DNA signal can dominate during expanding infections. Studies comparing multiple tissue analyses have attempted to increase the likelihood of detecting infected fish (i.e. sensitivity; Teska et al. 1995, Griffiths et al. 1996, Rhodes et al. 1998), but multiple tissue analysis is rarely used in practical applications. The advent and refinement of methods to distinguish DNA derived from viable cells has shown promise in environmental samples (e.g. Nocker et al. 2007) and may be extended to clinical efforts in the future.

Because ELISA is widely employed as a diagnostic method, it was useful to determine whether both ELISA and qPCR could be performed on the same tissue sample. In cases where limited tissue is available (e.g. juvenile fish), the advantages of conducting 2 assays from a single sample are obvious. We found substantial evidence that the non-soluble pellet generated during sample preparation for ELISA can be used for DNA extraction for qPCR analysis, producing results comparable to using frozen tissue. Because this pellet is typically discarded after removal of supernatant for ELISA analysis, dual analysis can truly be considered representative of a single sample, rather than from replicate tissue aliquots. If pellets have been appropriately stored at $-20^{\circ} \mathrm{C}$, retrospective analyses are also possible.

There are disadvantages to conducting dual analysis, most obviously for laboratories that are not already equipped and trained for real-time qPCR. A real-time qPCR machine is a major financial investment that would require a tangible benefit for its cost. The training for qPCR is different from that for ELISA, and personnel with conventional end-point PCR experience would need additional guidance to minimize false positives. DNA extraction and qPCR analysis reagents can easily triple the materials cost per sample, and a target DNA-free area needs to be designated for sample preparation and assay. Therefore, the decision to conduct dual analysis is probably most easily made in laboratories with existing qPCR experience and capacity.

In this report, we have shown that ELISA and qPCR diagnostics for Renibacterium salmoninarum can be performed on the same tissue sample, and that the 2 assays can provide non-redundant information. The convenience of conducting dual analysis on a single 
sample is useful for monitoring fish at nearly all life history stages. The model we have proposed for interpreting dual analysis results could provide improved information about the health status of individuals within a population or cohort. In the case of captively reared fish, dual analysis could detect emerging epidemics, allowing earlier implementation of remediation protocols. For captive broodstock programs that apply eggculling practices based on ELISA results, dual analysis may offer a more accurate assessment of the infection status of female broodstock than ELISA alone. Clearly, further observations from stock health evaluations and from experimental infections will be critical for assessing the value of the proposed model.

Acknowledgements. Funding for the collection of free-ranging juvenile salmon was provided by Fisheries and Oceans Canada and the Bonneville Power Administration. Bonneville Power Administration (Department of Energy) provided partial funding under contract no. 99-AI-17859, and we thank R. Deinhard (Pacific States Marine Fisheries Commission) for conducting the ELISA for the antibiotic-treated fish. Support was provided by Northwest Fisheries Science Center (NOAA Fisheries, US Department of Commerce) and in part by the Federal Columbia River Power System's Biological Opinion. Mention of trade names or commercial products is solely for the purpose of providing specific information and does not imply endorsement.

\section{LITERATURE CITED}

Arkoosh MR, Clemons E, Kagley AN, Stafford C and others (2004) Survey of pathogens in juvenile salmon Oncorhynchus spp. migrating through Pacific Northwest estuaries. J Aquat Anim Health 16:186-196

$>$ Bruno D, Collet B, Turnbull A, Kilburn R and others (2007) Evaluation and development of diagnostic methods for Renibacterium salmoninarum causing bacterial kidney disease (BKD) in the UK. Aquaculture 269:114-122

Chase DM, Pascho RJ (1998) Development of a nested polymerase chain reaction for amplification of a sequence of the p57 gene of Renibacterium salmoninarum that provides a highly sensitive method for detection of the bacterium in salmonid kidney. Dis Aquat Org 34:223-229

Chase DM, Elliott DG, Pascho RJ (2006) Detection and quantification of Renibacterium salmoninarum DNA in salmonid tissues by real-time quantitative polymerase chain reaction analysis. J Vet Diagn Invest 18:375-380

Cook M, Lynch WH (1999) A sensitive nested reverse transcriptase PCR assay to detect viable cells of the fish pathogen Renibacterium salmoninarum in Atlantic salmon (Salmo salar L.). Appl Environ Microbiol 65: 3042-3047

Fairgrieve WT, Masada CL, McAuley WC, Peterson ME and others (2005) Accumulation and clearance of orally administered erythromycin and its derivative, azithromycin, in juvenile fall Chinook salmon Oncorhynchus tshawytscha. Dis Aquat Org 64:99-106

Griffiths SG, Liska K, Lynch WH (1996) Comparison of kidney tissue and ovarian fluid from broodstock Atlantic salmon for detection of Renibacterium salmoninarum, and use of SKDM broth culture with Western blotting to increase detection in ovarian fluid. Dis Aquat Org 24:3-9

Hamel OS, Anderson JJ (2002) Relationship between antigen concentration and bacterial load in Pacific salmon with bacterial kidney disease. Dis Aquat Org 51:85-92

Jansson E, Lindberg L, Saker E, Aspan A (2008) Diagnosis of bacterial kidney disease by detection of Renibacterium salmoninarum by real-time PCR. J Fish Dis 31:755-763

Meyers TR, Short S, Farrington C, Lipson K, Geiger HJ, Gates R (1993) Establishment of a negative-positive threshold optical density value for the enzyme-linked immunosorbent assay (ELISA) to detect soluble antigen of Renibacterium salmoninarum in Alaskan Pacific salmon. Dis Aquat Org 16:191-197

> Meyers TR, Korn D, Glass K, Burton T, Short S, Lipson K, Starkey N (2003) Retrospective analysis of antigen prevalences of Renibacterium salmoninarum (Rs) detected by enzyme-linked immunosorbent assay in Alaskan Pacific salmon and trout from 1988 to 2000 and management of Rs in hatchery Chinook and coho salmon. J Aquat Anim Health 15:101-110

Miriam A, Griffiths SG, Lovely JE, Lynch WH (1997) PCR and probe-PCR assays to monitor broodstock Atlantic salmon (Salmo salar L.) ovarian fluid and kidney tissue for presence of DNA of the fish pathogen Renibacterium salmoninarum. J Clin Microbiol 35:1322-1326

Nocker A, Sossa-Fernandez P, Burr MD, Camper AK (2007) Use of propidium monoazide for live/dead distinction in microbial ecology. Appl Environ Microbiol 73:5111-5117

> Pascho RJ, Mulcahy D (1987) Enzyme-linked immunosorbent assay for a soluble antigen of Renibacterium salmoninarum, the causative agent of bacterial kidney disease. Can J Fish Aquat Sci 44:183-191

> Pascho RJ, Elliott DG, Streufert JM (1991) Brood stock segregation of spring chinook salmon Oncorhynchus tshawytscha by use of the enzyme-linked immunosorbent assay (ELISA) and the fluorescent antibody technique (FAT) affects the prevalence and levels of Renibacterium salmoninarum infection in progeny. Dis Aquat Org 12: $25-40$

> Pascho RJ, Goodrich TD, McKibben CL (1997) Evaluation by enzyme-linked immunosorbent assay (ELISA) of Renibacterium salmoninarum bacterins affected by persistence of bacterial antigens. J Aquat Anim Health 9:99-107

Pascho RJ, Chase D, McKibben CL (1998) Comparison of the membrane-filtration fluorescent antibody test, the enzyme-linked immunosorbent assay, and the polymerase chain reaction to detect Renibacterium salmoninarum in salmonid ovarian fluid. J Vet Diagn Invest 10:60-66

> Rhodes LD, Nilsson WB, Strom MS (1998) Sensitive detection of Renibacterium salmoninarum in whole fry, blood, and other tissues of Pacific salmon by reverse transcriptionpolymerase chain reaction. Mol Mar Biol Biotechnol 7: 270-279

> Rhodes LD, Coady AM, Deinhard RK (2004) Identification of a third msa gene in Renibacterium salmoninarum and the associated virulence phenotype. Appl Environ Microbiol 70:6488-6494

- Rhodes LD, Durkin C, Nance SL, Rice CA (2006) Prevalence and analysis of Renibacterium salmoninarum infection among juvenile Chinook salmon Oncorhynchus tshawytscha in North Puget Sound. Dis Aquat Org 71:179-190

Suzuki K, Sakai DK (2007) Real-time PCR for quantification of viable Renibacterium salmoninarum in chum salmon Oncorhynchus keta. Dis Aquat Org 74:209-223

Teska JD, Dawson A, Starliper CE, Tillinghast D (1995) A multiple-technique approach to investigating the presumptive low-level detection of Renibacterium salmoninarum at a broodstock hatchery in Maine. J Aquat Anim Health 7:251-256 